\title{
Syntactic Complexity in Second Language Academic Writing in English: Diversity on Display
}

\author{
Rosmawati, University of Sydney
}

\section{Introduction}

Despite its broad scope in the present day, the field of applied linguistics has been argued to have stemmed from foreign language teaching practice. This perhaps explains why research on foreign/second language learning (also acquisition/development) has continued to lie at the core of applied linguistic research (de Bot 2017). One of the main foci in studies on second language acquisition is the development of writing skills. Unanimously considered the most difficult skill to acquire (even in the first language (L1) context), writing has always been a challenge for many (Biber \& Gray 2016). Academic writing in a second language (L2) is yet another layer of challenge and has therefore attracted much attention in applied linguistic studies. Research on L2 academic writing, especially in English as a second language, has thus flourished - and will most likely continue to - along with the increasing trend of international education as well as the growing dominance of English as the world's lingua

\section{How to cite this book chapter:}

Rosmawati 2019. Syntactic Complexity in Second Language Academic Writing in English: Diversity on Display. In: Wright, C., Harvey, L. and Simpson, J. (eds.) Voices and Practices in Applied Linguistics: Diversifying a Discipline, pp. 251-270. York: White Rose University Press. DOI: https://doi.org/10.22599/BAAL1.o. Licence: CC BY-NC 4.0 
franca and the language of scientific dissemination (Ingvarsdóttir \& Arnbjörnsdóttir 2013; Manchón 2015).

For the past four or five decades, research in L2 writing has explored the multi-faceted dimensions of L2 writing performance and development from multiple perspectives and across different contexts (Manchón 2012; Polio \& Park 2016). Many studies looked at how L2 writing and/or writers developed across different levels of proficiency and took much interest in examining the development of linguistic complexity in L2 writing (see Ortega 2003; Wolfe-Quintero, Inagaki \& Kim 1998 for a synthesis). Among them, research on syntactic complexity and its development has always been one of the more prominent research lines. There is a wealth of research that investigated syntactic complexity as either a dependent variable, which is subject to the changes in proficiency levels, or as an important measure to gauge L2 performance.

However, as development is a process of change that is engrained in time, it is essential to include the aspect of time in the research design if the aim is to understand development. This view particularly aligns with the tenets of complex dynamic systems theory (CDST) (de Bot 2017; Larsen-Freeman 1997). This theory views the language learning process as a dynamic system and development as a dynamic change across time. CSDT endorses that development is highly idiosyncratic and characterised by both intra- and inter-individual variability (Verspoor et al. 2017), and hence highlighting idiosyncrasy, diversity and individual differences in both the language learners and their language development. It casts doubt on generalised uniformity in language development and supports the idea that diversity and variability are necessary features for development. Such a perspective makes CDST a suitable framework to investigate L2 writing performance and development and hence it is adopted in this chapter as the main framework to analyse the development of syntactic complexity and its diversity in L2 academic writing.

\section{Syntactic complexity}

Complexity, perhaps more appropriately termed as linguistic complexity, is one of the constructs in the complexity, accuracy and fluency (CAF) triad and possibly the most researched one. Although it has been defined and operationalised in a number of ways in the context of applied linguistic and writing research, the most commonly used definitions usually include the following points: elaborateness of language and evidence of variety in syntactic patterns (Ellis 2003; Foster \& Skehan 1996). However, complexity encompasses a concept broader than just these two points. Norris and Ortega (2009) pointed out that complexity is a multidimensional construct that comprises many different levels and sub-constructs, each nested in another, making itself a highly 
complex construct. Many researchers contend that complexity, along with the other two constructs in the CAF triad, can effectively capture the pivotal aspects of L2 performance and, as such, this triad has long been used as measurements of L2 performance/proficiency (Housen, Kuiken \& Vedder 2012).

According to the taxonomic model of L 2 complexity proposed by Bulté and Housen (2012), linguistic complexity can be investigated from different granularity levels, including the syntactic, lexical, morphological and phonological levels. Of these four levels, syntactic complexity is the most prevalent research area and has featured prominently in many studies on L2 writing. Syntactic complexity refers to the extent of elaborateness at the sentential, clausal and phrasal levels. It is operationalised in a great many ways to measure the different items in the diverse linguistic features that make up the structure of the language at these levels. However, these measures generally fall into one of two broad categories: frequency-based measures and length-based measures. Frequency-based measures include frequency counts of a certain linguistic unit (e.g., number of words (W), number of prepositional phrases (PrepP), number of dependent clauses (DepC) etc.) and ratios (e.g., dependent clause ratio (DepC/C), T-unit $^{1}$ complexity ratio (T/S) etc.), whereas length-based measures calculate the average length of a certain linguistic unit (e.g., mean length sentences (MLS), mean length T-unit (MLT), mean length clauses (MLC) etc.).

As a result, there is a large pool of syntactic complexity measures currently being employed in L2 writing studies. Some of these measures highly overlap with others, are quite confusing or are simply not informative enough owing to the misalignment with the characteristics of the spoken language instead of the written one (Kyle \& Crossley 2018; Lu 2011; Norris \& Ortega 2009). For example, MLT, the most commonly used measure (see Ortega 2003) for overall syntactic elaborateness in L2 writing studies, has recently been considered flawed for being not able to offer information about the type(s) of syntactic elaboration included (Kyle \& Crossley 2018). Merely knowing that the average length of a T-unit increases or decreases in a learner's writing does not offer sufficient insights into the type of elaboration that causes the changes as either or both the phrasal and clausal elaborations may motivate them. A closely related, and to some extent similar, measure - MLC - has also been undergoing the same criticism owing to its opaqueness and is being questioned for its primary focus on, and hence close alignment with, clausal complexity in assessing L2 writing.

This becomes an issue when such measures are employed to gauge syntactic complexity in academic writing as the features of syntactic complexity in academic writing are different from those of the spoken language and the other genres of writing due to the dense lexical packing and heavy nominalisation in academic prose (Biber \& Gray 2016). This results in much concise language in academic writing with more elaboration at the phrasal level than at the clausal/ 
sentential levels; hence measures of syntactic complexity that primarily and disproportionally focus on clausal elaboration are doubted for their suitability to measure syntactic complexity in academic writing.

\section{Phrasal complexity in academic writing}

Biber, Gray and Poonpon (2011) argued that assessing syntactic complexity in the written language using the same measures to gauge syntactic complexity in the spoken language is not ideal, if not inappropriate at all. This is due to the different characteristics in these two modes and the types of syntactic elaboration being dominant in each. While clausal elaboration is common in the spoken language, it is phrasal complexity that is the feature of the written language, especially in the academic register. Particularly in English, the language of academic writing is highly compact in its structure and meaning is usually conveyed through compressed phrasal devices, leading to higher phrasal complexity (Biber and Gray 2016).

Biber, Gray and Staples (2016) therefore recommended using phrasal complexity measures in complement with clausal complexity measures when assessing syntactic complexity in academic writing. This is in line with Norris and Ortega (2009), who noted the progression from coordination to subordination to phrasal-level complexification along with the increase in proficiency levels. Therefore, Norris and Ortega (2009) suggested employing a combination of measures in order to simultaneously gauge all three dimensions of syntactic complexity (i.e., coordination, subordination and phrasal-level complexification) through a more organic approach to L2 writing development.

As L2 learners progress towards the advanced proficiency level, they tend to employ more phrasal grammatical devices, especially those functioning as phrasal modifiers for head nouns, in their academic writing. As such, Verspoor, Lowie and van Dijk (2008) suggested employing a measure that is sensitive to the lengthening of complex nominal constructions when measuring syntactic complexity in academic writing at the advanced level. They proposed a finite verb-token ratio (FVTR), which is operationalised as the total number of words divided by the number of finite verbs (W/FV). This measure better reflects the internal complexity of a sentence, as it is sensitive to longer noun phrases and non-finite constructions.

Aligning with these recommendations, this chapter explores the development of syntactic complexity in L2 academic writing at the advanced level by measuring the sentential, clausal and phrasal elaboration with a special focus on complex nominalisation - one of the most representative traits of academic prose (Biber, Gray \& Poonpon 2011; Ortega 2015). Through analysing the academic essays written by four advanced learners of English over one academic year, this chapter explores the diversity and individual differences in the developmental patterns of syntactic complexity in L2 academic writing and detects if there was any statistically significant development in the data sets. 


\section{Complex dynamic systems theory (CDST)}

Underpinned by complex dynamic systems theory (CDST) (de Bot 2017; Larsen-Freeman 1997; Larsen-Freeman 2007; Lowie 2017; Verspoor 2017), this study regards language acquisition and development as a dynamic process and advocates that variability is an inherent property of such a process (de Bot \& Larsen-Freeman 2011; van Dijk, Verspoor \& Lowie 2011; Verspoor, Lowie \& van Dijk 2008). Consequently, language development in each individual learner may not take similar paths and may manifest in different patterns, resulting in great diversity in the learners' output. This theory has proven fruitful in accounting for many complex phenomena and is increasingly getting wider acceptance in the language research areas (de Bot 2015, Hiver \& AlHoorie 2016). This study is therefore conceived within the tenets of this theory and the findings are interpreted from the perspective of this theory.

Researchers within the CDST framework have offered a variety of statistical methods to explore non-linear data such as language developmental data. Among these, the discontinuity test is particularly suitable for detection of a developmental transition - a data point in the data set which may mark a gap (discontinuity in the statistic parlance) within that data set, and hence may indicate a possibility for a statistically significant development in the learners' data. This test was introduced by van Dijk and van Geert (2007), who explained in great detail the procedural steps for this analysis. The main feature of this test is its comparison with computer-generated continuous models (linear or otherwise) to see if such a data set can be generated by any continuous model. The idea is that if a continuous model can reproduce the data set, then it is very likely that there is no discontinuity within the data series. In other words, there is no developmental transition in that data series. This test is particularly suitable for time-series data that are process-oriented (such as language developmental data) and is a technique to detect development through variability analysis that considers both linear and non-linear models simultaneously.

The first step in this procedure is to look for the discontinuity indicators in the data. A visual inspection of the graphical representation of the data usually reveals a rather conspicuous peak (and/or valley) which might potentially mark a discontinuity in the data. Van Dijk and van Geert (2007) proposed three criteria to test whether such a potential point is indeed a discontinuity indicator: the peak criterion, the sub-pattern criterion and the membership criterion. The first criterion examines if a peak/valley can also be generated by the continuous models. The second criterion assesses if a particular data point (usually the visible peaks and/or valleys) divides the whole set into two sub-patterns, hence marking discontinuity in the series. Lastly, the third criterion tests if all the data points in a data set belong to a single data set. If a data point has the membership value of 1 , it belongs to the same data set with the other points. If it does not, it may suggest the existence of another data set and hence may signify discontinuity in the data set (See van Dijk \& van Geert 2007 on how to calculate the membership values). 
In reviewing the statistical significance of these data points, they are compared against the data simulated by four models (linear, quadratic, Loess and moving average). The $p$-values, which estimate the likelihood of that sample being drawn from the population generated by the simulated models, are reported after being compared to 10,000 Monte Carlo simulations (refer to van Geert, Steenbeek \& Kunnen 2012 for details on how to run the simulations) to determine if the null hypothesis can or cannot be rejected (Norris 2015). When a $p$-value is statistically significant (being less than 0.05 ), then it is scarcely possible that the result is due to random chance. In other words, the detected discontinuity is statistically valid. This procedure was adopted in this study.

\section{The study}

This study aims to explore the development of syntactic complexity in L2 writing and the diverse elaboration strategies the learners employed in making their writing more complex in order to align with the conventions of academic writing in English. It explores the non-linear trend in L2 writing development from the perspectives of CDST and examines if a developmental transition took place during the observed course of development.

\section{Research design and participants}

This study was designed as multiple case studies of a longitudinal nature. The participants were four international students who were studying in a one-year coursework postgraduate education programme in the TESOL major in Australia. English was not the first language for all the participants (see Table 9 for further details). The data were collected during this one-year period.

The study was approved by the Human Research Ethics Committee (The University of Sydney) (Ref: GD/ADS) and informed consent to participate in this study was obtained by all four participants mentioned in Table 9.

Table 9: Participants' description.

\begin{tabular}{|c|c|c|c|c|}
\hline No. & Participants (pseudonym) & Gender, age & L1 background & IELTS score \\
\hline 1 & Arun & Male, 30 & Thai & 7.0 \\
\hline 2 & Machiko & Female, 32 & Japanese & 6.5 \\
\hline 3 & Jaeri & Female, 28 & Korean & 6.5 \\
\hline 4 & Yingying & Female, 26 & Chinese & 6.5 \\
\hline
\end{tabular}




\section{Data collection and coding}

The data were the academic essays ${ }^{2}$ written by these four postgraduate students (corpus size 220,000 words, comprising 20 measurement points per participant), which were collected during the period of one academic year. A $10 \%$ sample was then manually coded with a set of measures (see Table 10) judiciously selected to gauge syntactic complexity at three different levels (i.e., at the overall/sentential level, the clausal level and the phrasal level). Such a combination aligns with the recommendation to employ phrasal complexity measures

Table 10: Syntactic complexity measures.

\begin{tabular}{|c|c|c|c|c|}
\hline Type & Level & Measure & Abbreviation & Formula \\
\hline \multirow[t]{3}{*}{ Ratio } & Overall & $\begin{array}{l}\text { Finite verb- } \\
\text { token ratio }\end{array}$ & FVTR & $\begin{array}{c}\text { Number of words/number } \\
\text { of finite verbs }\end{array}$ \\
\hline & $\begin{array}{c}\text { Clausal } \\
\text { level }\end{array}$ & $\begin{array}{c}\text { Mean length } \\
\text { sentence }\end{array}$ & MLS & $\begin{array}{c}\text { Number of words/number } \\
\text { of sentences }\end{array}$ \\
\hline & $\begin{array}{c}\text { Phrasal } \\
\text { level }\end{array}$ & $\begin{array}{l}\text { Mean length } \\
\text { clause }^{3}\end{array}$ & MLC & $\begin{array}{c}\text { Number of words/number } \\
\text { of clauses }\end{array}$ \\
\hline \multirow[t]{6}{*}{$\begin{array}{l}\text { Frequency } \\
\text { count }\end{array}$} & \multirow[t]{6}{*}{$\begin{array}{l}\text { Complex } \\
\text { nominal } \\
\text { structures } \\
\text { (CNS) }\end{array}$} & $\begin{array}{l}\text { Pre-modified } \\
\text { CNS }\end{array}$ & CNS - Pre & $\begin{array}{c}\text { Number of CNS with a } \\
\text { head noun being modified } \\
\text { by a word/group of words } \\
\text { preceding it }\end{array}$ \\
\hline & & $\begin{array}{l}\text { Post-modified } \\
\text { CNS }\end{array}$ & CNS - Post & $\begin{array}{c}\text { Number of CNS with a } \\
\text { head noun being modified } \\
\text { by a word/group of words } \\
\text { following it }\end{array}$ \\
\hline & & $\begin{array}{l}\text { Pre- \& post- } \\
\text { modified CNS }\end{array}$ & $\begin{array}{c}\text { CNS - } \\
\text { Pre- \& Post- }\end{array}$ & $\begin{array}{c}\text { Number of CNS with } \\
\text { a head noun being } \\
\text { concurrently modified by } \\
\text { a word/group of words } \\
\text { preceding it and following } \\
\text { it }\end{array}$ \\
\hline & & $\begin{array}{l}\text { CNS modified } \\
\text { by a nominal } \\
\text { clause }\end{array}$ & CNS - NomC & $\begin{array}{c}\text { Number of CNS with a } \\
\text { head noun being modified } \\
\text { by a nominal clause }\end{array}$ \\
\hline & & $\begin{array}{l}\text { CNS modified } \\
\text { by a relative } \\
\text { clause }\end{array}$ & CNS - RelC & $\begin{array}{l}\text { Number of CNS with a } \\
\text { head noun being modified } \\
\text { by a relative clause }\end{array}$ \\
\hline & & $\begin{array}{l}\text { CNS modified } \\
\text { by a non-finite } \\
\text { clause }\end{array}$ & CNS - NFC & $\begin{array}{l}\text { Number of CNS with a } \\
\text { head noun being modified } \\
\text { by a non-finite clause }\end{array}$ \\
\hline
\end{tabular}


to complement clausal complexity measures (Biber, Gray \& Staples 2016; De Clercq \& Housen 2017; Kyle \& Crossley 2018). In addition, frequency count measures were employed in this study to reveal the distribution of different types of complex nominal structures in the data and to highlight the diversity of strategies (as listed in Table 10) the learners used in making their writing more complex.

\section{Data exploration and analysis}

The data were first plotted in developmental graphs to visualise the dynamism along the trajectories. Some examples from the participants' essay excerpts are shown below to illustrate the phenomena captured in the graphs. The data were then submitted to a discontinuity test to examine if developmental transitions occurred, and the $p$-values are reported to establish whether the null hypothesis can be rejected or not - or in other words, whether a significant transition is detected in the data set or not. Lastly, the proportions of each type of complex nominals in the data were presented in tables and discussed through examples from the participants' essay excerpts.

\section{Results}

The data show that the development of syntactic complexity in second language learners' written production was non-linear and that the developmental path of each learner was indeed idiosyncratic as no two participants in this study showed a similar developmental path. As can be seen in Figure 17, the line graphs plotting the development of overall syntactic complexity (as measured by the finite verb-token ratio) in the essays written by the four participants over one academic year exhibit a high degree of fluctuation with the peaks and valleys along the trajectories.

The fluctuation evidenced in this data set mostly fell within the value of 10 to 20. There were, however, some sharp peaks and deep valleys beyond this range. For example, in Arun's data, there was one deep valley (essay no. 6) below the value of 10 and one sharp peak (essay no. 8) above the value of 20 . The following two sentences, extracted from Arun's essays no. 6 and no. 8, respectively, provide an illustrative example of how the overall syntactic complexity differed in the two essays.

\section{Examples:}

[1] This text will be applied in the classroom where learners are at intermediate level, age around 18 years old.

(Excerpt from Arun's essay no. 6; finite verbs in bold; errors not corrected) (Word count: 19; finite verb count: $2 ; \mathrm{W} / \mathrm{FV}=9.5$ ) 

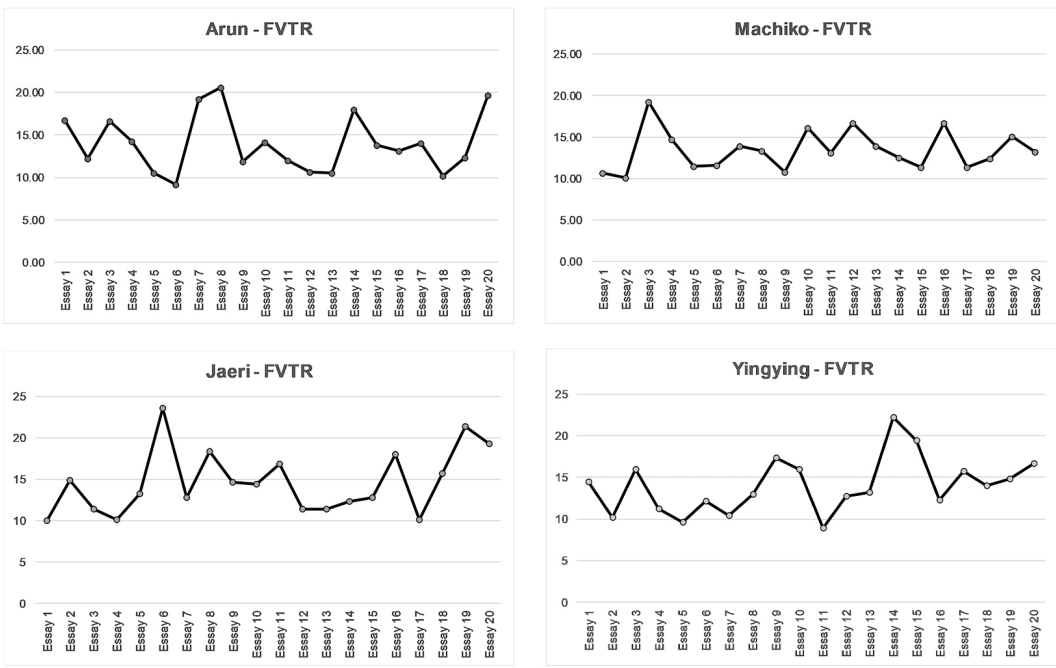

Figure 17: Overall syntactic complexity index (Copyright Rosmawati, CC BY-NC 4.0).

[2] Some of the studies focused on the written production of EFL students' narratives both in Thai and English and recently with the production of narratives by advanced bilingual students who live in the States.

(Excerpt from Arun's essay no. 8; finite verbs in bold; errors not corrected) (Word count: 34 ; finite verb count: $2 ; \mathrm{W} / \mathrm{FV}=17$ )

The overall syntactic complexity index of the second sentence is nearly twice that of the first sentence. This indicates a high degree of variability among data points, which is visually represented by the peaks and valleys in the graphs in Figure 17. These ebbs and flows not only confirm the main tenets of the DST framework regarding the dynamics of language development but are also in line with the results from many studies on the development of complexity in L2 writing, for example Spoelman and Verspoor (2010), de Bot et al. (2012), Polat and Kim (2014) and Yang and Sun (2015), who reported a high degree of fluctuation and non-linearity in their data.

To examine whether the sharp peaks and deep valleys evidenced in each participant's writing constituted a developmental transition, the data points were submitted to a discontinuity test which compared them against a $3 \times 4$ matrix, consisting of three test criteria and four models to detect evidence of discontinuity in the data (see the previous section for details). The first step was to test the data against the peak criterion test and the results are presented in Table 11.

As can be seen in Table 11 the $p$-values for Arun's and Yingying's data are above 0.05 and therefore not statistically significant. However, there are some 
Table 11: $p$-values for tests against the peak criterion.

\begin{tabular}{|c|c|c|c|c|c|}
\hline \multirow{2}{*}{ Participants } & \multirow{2}{*}{ Peak criterion } & \multicolumn{3}{|c|}{$p$-values when compared to each model } \\
\cline { 3 - 6 } & & Linear & Quadratic & Loess & $\begin{array}{c}\text { Moving } \\
\text { average }\end{array}$ \\
\hline \multirow{2}{*}{ Arun } & Absolute peak & 0.28 & 0.26 & 0.26 & 0.76 \\
\cline { 3 - 6 } & Relative peak & 0.29 & 0.22 & 0.36 & 0.65 \\
\hline \multirow{2}{*}{ Machiko } & Absolute peak & $0.03^{*}$ & $0.02^{*}$ & $0.02^{*}$ & 0.24 \\
\cline { 2 - 6 } & Relative peak & $0.03^{*}$ & $0.007^{*}$ & $0.02^{*}$ & 0.14 \\
\hline \multirow{2}{*}{ Jaeri } & Absolute peak & $0.038^{*}$ & 0.055 & 0.104 & 0.103 \\
\cline { 2 - 6 } & Relative peak & $0.024^{*}$ & $0.04^{*}$ & 0.185 & 0.137 \\
\hline \multirow{2}{*}{ Yingying } & Absolute peak & 0.11 & 0.06 & 0.45 & 0.68 \\
\cline { 2 - 6 } & Relative peak & 0.18 & 0.09 & 0.16 & 0.51 \\
\hline
\end{tabular}

* statistically significant $(\mathrm{p}=<0.05)$.

Table 12: $p$-values for tests against the sub-pattern criterion.

\begin{tabular}{|c|c|c|c|c|}
\hline Sub-pattern criterion & Arun & Machiko & Jaeri & Yingying \\
\hline$p$-value & 0.44 & 0.0982 & $0.05^{\star}$ & 0.89 \\
\hline
\end{tabular}

statistically significant $p$-values in Machiko's and Jabri's data, which may indicate a possible discontinuity in their data. Nevertheless, when tested against the second criterion (i.e., the sub-pattern criterion), statistical significance was only reached in Jaeri's data (see Table 12). This suggests a possibility that there were two distinct patterns in the data, marked by a discontinuous point in-between.

Lastly, these data sets were tested against the membership criterion and the results indicate that the membership value of all the data points was one. In other words, the data of each participant showed characteristics of one continuous data set and no evidence of discontinuity was detected under this criterion. Hence, the null hypothesis for this criterion could not be rejected.

Table 13 summarises the results of testing the constructs against the three test criteria; it shows whether or not the criteria were satisfied and, consequently, whether or not the high value did mark a developmental transition. As can be seen in Table 13, none of the data sets satisfied more than half of the test criteria in this study, and therefore it is concluded that none of the participants' writing showed a significant developmental transition during the observation period of one academic year.

Despite having no significant developmental transitions detected in the observation period, all the participants' data displayed idiosyncrasy and a high diversity in the strategies they used to make their writing complex and more 
Table 13: A summary of the discontinuity detection analysis.

\begin{tabular}{|c|c|c|c|c|}
\hline Participants & $\begin{array}{c}\text { Membership } \\
\text { criterion }\end{array}$ & Peak criterion & $\begin{array}{c}\text { Sub-pattern } \\
\text { criterion }\end{array}$ & $\begin{array}{c}\text { Developmental } \\
\text { transition }\end{array}$ \\
\hline Arun & No & No & No & No \\
\hline Machiko & No & Yes & No & No \\
\hline Jaeri & No & No $^{4}$ & Yes & No \\
\hline Yingying & No & No & No & No \\
\hline
\end{tabular}

Table 14: Clausal and phrasal complexity indices in the four participants' essays.

\begin{tabular}{|c|c|c|c|c|c|c|c|c|}
\hline & \multicolumn{2}{|c|}{ Arun } & \multicolumn{2}{c|}{ Machiko } & \multicolumn{2}{c|}{ Jaeri } & \multicolumn{2}{c|}{ Yingying } \\
\hline & MLS & MLC & MLS & MLC & MLS & MLC & MLS & MLC \\
\hline Essay 1 & 41.60 & 9.90 & 16.77 & 7.79 & 22.00 & 6.67 & 27.00 & 8.64 \\
\hline Essay 2 & 28.57 & 9.52 & 20.80 & 5.94 & 28.57 & 9.09 & 20.50 & 7.59 \\
\hline Essay 3 & 29.14 & 7.03 & 34.50 & 6.68 & 29.86 & 8.36 & 22.56 & 9.23 \\
\hline Essay 4 & 23.89 & 11.32 & 20.50 & 7.32 & 29.43 & 8.24 & 20.10 & 7.18 \\
\hline Essay 5 & 23.78 & 6.90 & 18.36 & 6.97 & 25.38 & 8.46 & 17.75 & 7.89 \\
\hline Essay 6 & 25.13 & 5.91 & 24.00 & 6.97 & 41.20 & 9.36 & 16.77 & 8.72 \\
\hline Essay 7 & 29.14 & 9.27 & 18.08 & 6.78 & 35.33 & 10.10 & 21.50 & 7.96 \\
\hline Essay 8 & 34.50 & 14.79 & 20.40 & 6.80 & 34.67 & 13.00 & 17.33 & 8.00 \\
\hline Essay 9 & 36.17 & 8.04 & 27.00 & 6.75 & 27.00 & 9.00 & 27.38 & 11.53 \\
\hline Essay 10 & 34.33 & 7.92 & 26.00 & 7.70 & 36.50 & 9.95 & 18.00 & 10.80 \\
\hline Essay 11 & 31.29 & 8.76 & 16.69 & 7.48 & 30.43 & 8.88 & 20.50 & 7.88 \\
\hline Essay 12 & 33.83 & 6.77 & 22.33 & 8.04 & 30.43 & 7.10 & 16.38 & 7.34 \\
\hline Essay 13 & 40.60 & 5.80 & 21.30 & 7.34 & 68.67 & 6.65 & 20.70 & 8.63 \\
\hline Essay 14 & 35.17 & 7.81 & 20.00 & 8.46 & 35.67 & 8.56 & 23.33 & 7.24 \\
\hline Essay 15 & 33.83 & 6.34 & 18.73 & 6.87 & 40.60 & 10.15 & 23.67 & 9.68 \\
\hline Essay 16 & 33.67 & 7.48 & 20.50 & 6.03 & 29.14 & 7.85 & 20.09 & 7.89 \\
\hline Essay 17 & 27.00 & 10.29 & 23.11 & 8.00 & 40.40 & 7.21 & 30.00 & 11.05 \\
\hline Essay 18 & 21.90 & 7.06 & 18.36 & 8.78 & 66.33 & 8.29 & 20.60 & 8.96 \\
\hline Essay 19 & 23.78 & 7.13 & 21.90 & 7.82 & 41.20 & 8.96 & 20.09 & 9.61 \\
\hline Essay 20 & 26.75 & 9.30 & 18.36 & 7.77 & 40.60 & 7.81 & 24.67 & 8.88 \\
\hline
\end{tabular}


aligning with the characteristics of academic writing in English. The features of clausal elaboration and phrasal elaboration were both evidenced in their data set and are explored in this study through the following measures.

Table 14 shows that the average length of the sentences (MLS) and the average length of clauses (MLC) in each participant's writing differed greatly. The data suggest that Arun's sentences were longer than the other participants' and that both Machiko's and Yingying's sentences were relatively shorter. A further investigation into the raw data revealed the potential causes for such an outward manifestation. As can be seen in example no. 3, Yingying's sentences were shorter because they were mainly simple sentences. Machiko, on the other hand, combined her sentences through clausal elaboration. Example no. 4 shows that she used as many as three dependent clauses to make her sentence elaborate and complex. This, however, was not the strategy that Arun preferred in his writing. Example no. 5 shows that Arun's main strategy for elaboration was through phrasal complexification.

\section{Examples:}

[3] However, there are at least two main limitations among the relevant previous studies. One limitation is about the participants. Most participants in relevant studies were all in beginner-level.

(Excerpt from Yingying's essay no. 18; errors not corrected)

(Sentence counts: 3; word count: 29; dependent clause count: 0 , all simple sentences)

[4] ( ${ }^{1}$ Although Masa mentioned) ('that he didn't read anything outside the classroom except homework), [he liked reading Japanese novels] ( ${ }^{3}$ when he was in Japan).

(Excerpt from Machiko's essay no. 2; open brackets and numbers added; errors not corrected)

(Sentence count: 1; word count: 23; dependent clause count: 3)

[5] In the past, the major focus of the studies in Thai and English narratives has moved to the production of L2 writing, not on the narrative texts themselves.

(Excerpt from Arun's essay no. 8; errors not corrected)

(Sentence count: 1 ; word count: 28 ; dependent clause count: 0 )

A further comparison of the phrasal complexity index (MLC) in Arun's and Machiko's data reveals a striking difference between these two participants. Machiko's phrasal complexity index was much lower than Arun's. It seems to suggest that she felt comfortable using clausal elaboration in her writing, as can be seen in the following example.

Example:

[6] ( ${ }^{1}$ While most researchers and educators agree with the effectiveness ( ${ }^{2}$ to read aloud in classroom)), there are few discussions about the processes $\left({ }^{3}\right.$ that teachers use ( ${ }^{4}$ to implement the read-aloud)) and it is still less clear ( ${ }^{5}$ how 
teachers conduct read-aloud in classroom effectively) and ( ${ }^{6}$ what the essential components are) ('to be successful in read-aloud teaching).

(Excerpt from Machiko's essay no. 3; open brackets and numbers added; errors not corrected)

(Sentence count: 1; dependent clause count: 7)

A closer inspection into the data set revealed that Machiko did use the complex nominalisation strategy frequently, and so did the other participants. As can be seen in Table 15, all the participants in this study used complex nominalisation strategy in their writing to a differing degree. In many cases, the number of occurrences of these structures in Machiko's essays was even a little higher than in Arun's. This is probably due to the combination with clausal modification strategy she used to form complex noun structures. This strategy seemed to feature in all her essays and constituted a relatively large proportion of the modifications used in essay no. 3, where the highest syntactic complexity was evident. Example no 7 illustrates the concurrent use of subordination and complex nominal structures in Machiko's writing. Jaeri, on the other hand, employed coordination strategies to form complex nominals in her writing, as can be seen in example no. 8 .

Examples:

[7] It is expected [that an exploration of the variables affecting the effectiveness of reading aloud will support Japanese EFL teachers with designing lessons [in order to develop students' reading literacy of English as a foreign language]]. (Excerpt from Machiko's essay no. 10; underlines and brackets added; errors not corrected)

[8] It was the policy of the South Korean Education managers, [that [if you had a BA in virtually anything, and ${ }_{1}$ you were a native English person [who spoke fluent English]], then that was good enough]; at first being American or Cana$\underline{\text { dian }}$ was also a prerequisite, $\underline{\text { but }}_{2}$ in time, things changed over the last decade or so and $\underline{\text { now }}_{3}$ anyone of an English first language background, is acceptable. (Excerpt from Jaeri's essay no. 18; bold, underlines and numbers added; errors not corrected)

(Clausal coordination: 3; phrasal coordination: 2)

An exploration into the types of modification all the participants used to form complex noun structures revealed that the main strategy they used was pre-modification. However, the proportion of use differed greatly between participants as well as between essays by the same participants, as can be seen in Table 15. Such a finding is expected since variability, both intra- and inter-individual, is one of the characteristics of a dynamic system (de Bot 2008; de Bot, Lowie \& Verspoor 2005; Larsen-Freeman 2007; van Dijk, Verspoor \& Lowie 2011; Verspoor, Lowie \& van Dijk 2008) and it confirms the idiosyncrasy and diversity in each language learner's developmental path. 
Table 15: Complex nominal structures in the four participants' essays.

\begin{tabular}{|l|c|c|c|c|c|c|c|c|c|c|c|c|}
\hline & \multicolumn{7}{|c}{ Arun } & \multicolumn{7}{c|}{ Machiko } \\
\hline & Pre- & Post- & $\begin{array}{c}\text { Pre- } \\
\text { \& } \\
\text { Post- }\end{array}$ & $\begin{array}{c}\text { Nom } \\
\text { C }\end{array}$ & $\begin{array}{c}\text { Rel } \\
\text { C }\end{array}$ & NFC & Pre- & Post- & $\begin{array}{c}\text { Pre- } \\
\text { \& } \\
\text { Post- }\end{array}$ & $\begin{array}{c}\text { Nom } \\
\text { C }\end{array}$ & $\begin{array}{c}\text { Rel } \\
\text { C }\end{array}$ & NFC \\
\hline Essay 1 & 19 & 8 & 3 & 5 & 2 & 0 & 17 & 7 & 6 & 7 & 1 & 1 \\
\hline Essay 2 & 16 & 12 & 0 & 2 & 3 & 2 & 16 & 1 & 4 & 11 & 1 & 1 \\
\hline Essay 3 & 14 & 4 & 5 & 1 & 2 & 1 & 9 & 11 & 5 & 14 & 2 & 1 \\
\hline Essay 4 & 19 & 12 & 5 & 2 & 2 & 0 & 25 & 9 & 0 & 9 & 3 & 0 \\
\hline Essay 5 & 14 & 13 & 0 & 5 & 3 & 3 & 24 & 9 & 2 & 11 & 0 & 1 \\
\hline Essay 6 & 11 & 1 & 1 & 8 & 7 & 2 & 19 & 3 & 6 & 13 & 3 & 1 \\
\hline Essay 7 & 17 & 4 & 7 & 5 & 0 & 1 & 14 & 10 & 5 & 10 & 1 & 3 \\
\hline Essay 8 & 32 & 5 & 4 & 3 & 2 & 1 & 12 & 8 & 4 & 13 & 0 & 1 \\
\hline Essay 9 & 14 & 6 & 1 & 6 & 1 & 2 & 16 & 6 & 3 & 11 & 4 & 1 \\
\hline Essay 10 & 18 & 8 & 3 & 8 & 3 & 1 & 18 & 13 & 6 & 6 & 3 & 3 \\
\hline Essay 11 & 24 & 6 & 2 & 4 & 6 & 1 & 18 & 8 & 4 & 6 & 1 & 6 \\
\hline Essay 12 & 15 & 2 & 1 & 5 & 4 & 0 & 20 & 7 & 2 & 8 & 0 & 1 \\
\hline Essay 13 & 9 & 1 & 3 & 8 & 4 & 4 & 25 & 5 & 3 & 13 & 0 & 1 \\
\hline Essay 14 & 15 & 5 & 1 & 5 & 3 & 5 & 26 & 8 & 2 & 11 & 1 & 1 \\
\hline Essay 15 & 7 & 5 & 1 & 7 & 2 & 5 & 19 & 5 & 1 & 6 & 3 & 2 \\
\hline Essay 16 & 21 & 2 & 4 & 7 & 2 & 0 & 12 & 4 & 3 & 7 & 0 & 3 \\
\hline Essay 17 & 16 & 8 & 3 & 3 & 3 & 1 & 16 & 4 & 6 & 4 & 6 & 1 \\
\hline Essay 18 & 21 & 7 & 2 & 6 & 5 & 1 & 11 & 7 & 4 & 5 & 5 & 1 \\
\hline Essay 19 & 19 & 2 & 4 & 9 & 2 & 0 & 19 & 9 & 4 & 10 & 1 & 1 \\
\hline Essay 20 & 18 & 6 & 2 & 6 & 2 & 1 & 24 & 6 & 5 & 4 & 2 & 1 \\
\hline
\end{tabular}

\section{Discussion}

The findings of this study confirm some major propositions in the L2 writing research field and lend support to the hypothesis that academic writing at the advanced level shows characteristics of concise/compact language with more elaboration at the phrasal level and less dependence on clausal elaboration (Norris \& Ortega 2009). Arun's writing, for example, showed a high proportion of complex nominal structures, which is the main trait of academic language. This was also reflected in the other participants' writing. All the participants in this study employed a variety of complexification strategies to make their writing more complex and more academic-like. 
Table 15: Continued.

\begin{tabular}{|c|c|c|c|c|c|c|c|c|c|c|c|c|}
\hline & \multicolumn{6}{|c|}{ Jaeri } & \multicolumn{6}{|c|}{ Yingying } \\
\hline & Pre- & Post- & $\begin{array}{c}\text { Pre- } \\
\& \\
\text { Post- }\end{array}$ & $\begin{array}{c}\text { Nom } \\
\text { C }\end{array}$ & $\begin{array}{c}\text { Rel } \\
\text { C }\end{array}$ & NFC & Pre- & Post- & $\begin{array}{l}\text { Pre- } \\
\& \\
\text { Post- }\end{array}$ & $\begin{array}{c}\text { Nom } \\
\text { C }\end{array}$ & $\begin{array}{c}\text { Rel } \\
\text { C }\end{array}$ & NFC \\
\hline Essay 1 & 33 & 1 & 4 & 4 & 3 & 1 & 9 & 12 & 5 & 4 & 0 & 0 \\
\hline Essay 2 & 21 & 5 & 5 & 1 & 2 & 1 & 12 & 11 & 0 & 5 & 3 & 3 \\
\hline Essay 3 & 16 & 4 & 9 & 3 & 5 & 1 & 23 & 5 & 3 & 4 & 1 & 3 \\
\hline Essay 4 & 23 & 1 & 4 & 9 & 0 & 1 & 18 & 7 & 3 & 7 & 3 & 1 \\
\hline Essay 5 & 22 & 4 & 2 & 2 & 1 & 1 & 16 & 5 & 2 & 6 & 2 & 1 \\
\hline Essay 6 & 23 & 4 & 2 & 2 & 0 & 4 & 17 & 3 & 3 & 1 & 4 & 0 \\
\hline Essay 7 & 20 & 1 & 4 & 0 & 2 & 3 & 27 & 6 & 3 & 3 & 1 & 1 \\
\hline Essay 8 & 15 & 5 & 3 & 0 & 3 & 1 & 22 & 7 & 2 & 3 & 1 & 1 \\
\hline Essay 9 & 16 & 3 & 4 & 2 & 2 & 3 & 18 & 11 & 10 & 3 & 3 & 1 \\
\hline Essay 10 & 21 & 6 & 1 & 2 & 3 & 2 & 14 & 5 & 2 & 2 & 2 & 0 \\
\hline Essay 11 & 28 & 2 & 3 & 3 & 2 & 1 & 9 & 6 & 6 & 5 & 3 & 0 \\
\hline Essay 12 & 15 & 3 & 3 & 7 & 2 & 3 & 23 & 5 & 2 & 3 & 1 & 3 \\
\hline Essay 13 & 7 & 4 & 1 & 4 & 1 & 1 & 22 & 3 & 6 & 7 & 0 & 0 \\
\hline Essay 14 & 17 & 7 & 1 & 1 & 5 & 1 & 14 & 4 & 3 & 5 & 0 & 6 \\
\hline Essay 15 & 22 & 1 & 2 & 5 & 3 & 1 & 22 & 6 & 2 & 4 & 1 & 3 \\
\hline Essay 16 & 29 & 2 & 3 & 7 & 2 & 0 & 16 & 6 & 7 & 5 & 2 & 2 \\
\hline Essay 17 & 26 & 10 & 0 & 1 & 5 & 5 & 23 & 5 & 12 & 5 & 3 & 1 \\
\hline Essay 18 & 25 & 3 & 3 & 1 & 2 & 2 & 28 & 3 & 6 & 4 & 2 & 1 \\
\hline Essay 19 & 19 & 4 & 6 & 4 & 3 & 4 & 23 & 5 & 9 & 3 & 4 & 1 \\
\hline Essay 20 & 23 & 2 & 2 & 5 & 2 & 4 & 22 & 11 & 3 & 5 & 0 & 2 \\
\hline
\end{tabular}

However, the characteristics of their usage were different. While Arun produced many dependent clauses in his writing, those clauses were not particularly long. Very frequently, he used a complex nominalisation strategy in combination with coordination at the (noun) phrasal level to make his writing more complex. The most common way he used to produce complex nominal structures was pre-modification. He also used much post-modification and clausal modification to make the complex nominal structures longer. Machiko, however, tended to use non-finite clauses and coordination of these clauses to lengthen her sentences. When compared to the other participants' writing, her writing was made up of a higher proportion of complex sentences due to her frequent uses of clausal subordination strategy. Jaeri, on the other hand, 
increased her syntactic complexity most frequently by producing longer complex nominal structures and joining them via coordination before finite verbs. Yingying, the last participant in this study, produced more non-finite clauses to increase the length and complexity of her writing. However, Yingying's writing was characterised by a high proportion of simple sentences, which she sometimes combined into compound sentences through phrasal coordination in her essays.

The differences, nevertheless, existed not only between participants but also within participants. Machiko, for example, sometimes preferred to use the subordination strategy to make her sentences more complex; at other times she tended to use coordination strategies more. At different times, she used a different combination of the complexification strategies, resulting in intra-individual differences. These differences, along with inter-individual differences, result in considerable diversity in L2 academic writing.

\section{Conclusion}

The manifestation of syntactic complexity in each participant's writing had their own distinctive patterns and hence displayed high diversity although they might, to some extent, share some similarities, largely due to the rather exclusive characteristics of academic writing. However, despite these shared features, each participant maintained their individual styles in their writing and none of them converged perfectly with each other.

Although no significant developmental transitions were detected within the current data set in this study, this does not mean that the learners' writing was not developing. From a dynamic systems perspective, such a phenomenon is not discounted as non-development. In fact, the learners were growing within a relatively stable state (van Geert 2009). Once they reached a threshold point (i.e., a critical level to be reached before a massive reconstruction and selforganisation can occur), their interlanguage system will move out of its current state and commence the next stage of development (van Geert 2011; Witherington 2007). The observation period of one academic year may be too short a period for such significant development to take place, especially given that all the participants in this study were already at the advanced end of proficiency level. As such, a future attempt with a longer observation period (and perhaps complemented with qualitative inquiries) is recommended.

\section{Endnotes}

${ }^{1}$ Minimal Terminable Unit. A T-unit includes an independent clause and all the dependent clauses attached to it.

2 These essays were the assignments submitted by the participants to their unit coordinators as part of the requirements for the units of study they 
were enrolled in. With their consent, these essays were collected by the researcher and serve as the data in this project.

${ }^{3}$ Yoon (2017) demonstrated through a factor analysis that MLT loaded strongly on one factor along with other clausal-level syntactic measures while MLC, with phrasal-level measures, loaded strongly on another factor. His study provided empirical evidence that these two length-based measures gauge syntactic complexity at different granularity (i.e., at the clausal and the phrasal levels, respectively).

${ }^{4}$ In this study, a criterion was considered met if the $p$-values were statistically significant for more than $50 \%$ of the models tested. As such, Jaeri's data did not meet the peak criterion as only three (out of the eight) $p$-values were statistically significant under this criterion.

\section{References}

Biber, D. and Gray, B. 2016 Grammatical complexity in academic English. Cambridge: Cambridge University Press.

Biber, D., Gray, B. and Poonpon, K. 2011 Should we use characteristics of conversation to measure grammatical complexity in L2 writing development? TESOL Quarterly, 45(1): 5-35. DOI: https://doi.org/10.5054/ tq.2011.244483

Biber, D., Gray, B. and Staples, S. 2016 Predicting patterns of grammatical complexity across language exam task types and proficiency levels. Applied Linguistics, 37(5): 639-668. DOI: https://doi.org/10.1093/applin/amu059

Bulté, B. and Housen, A. 2012 Defining and operationalising L2 complexity. In Housen, A., Kuiken, F., and Vedder, I. (eds), Dimensions of L2 performance and proficiency: Complexity, accuracy, and fluency in SLA. Amsterdam/ Philadelphia, PA: John Benjamins. pp. 21-46.

de Bot, K. 2008 Introduction: Second language development as a dynamic process. The Modern Language Journal, 92(2): 166-178. DOI: https://doi. org/10.1111/j.1540-4781.2008.00712.x

de Bot, K. 2015 A history of applied linguistics: From 1980 to present. Abingdon, Oxon: Routledge.

de Bot, K. 2017 Complexity theory and dynamic systems theory: Same or different? In Ortega, L. and Han, Z. (eds), Complexity Theory and language development: In celebration of Diane Larsen-Freeman. Amsterdam/Philadelphia, PA: John Benjamins. pp. 51-58.

de Bot, K., Chan, H., Lowie, W., Plat, R. and Verspoor, M. 2012 A dynamic perspective on language processing and development. Dutch Journal of Applied Linguistics, 1(2): 188-218. DOI: https://doi.org/10.1075/dujal.1.2.03deb

de Bot, K. and Larsen-Freeman, D. 2011 Researching second language development from a dynamic systems theory perspective. In Verspoor, M., de Bot, K. and Lowie, W. A dynamic systems approach to second language development. Amsterdam/Philadelphia, PA: John Benjamins. pp. 5-23. 
de Bot, K., Lowie, W. and Verspoor, M. 2005 Second language acquisition: An advanced resource book. Abingdon, Oxon: Routledge.

De Clercq, B. and Housen, A. 2017 A cross-linguistic perspective on syntactic complexity in L2 development: Syntactic elaboration and diversity. The Modern Language Journal, 101(2): 315-334. DOI: https://doi.org/10.1111/ modl.12396

Ellis, R. 2003 Task-based language learning and teaching. Oxford: Oxford University Press.

Foster, P. and Skehan, P. 1996 The influence of planning and task type on second language performance. Studies in Second Language Acquisition, 18(3): 299-323. DOI: https://doi.org/10.1017/S0272263100015047

Hiver, P. and Al-Hoorie, A. 2016 A dynamic ensemble for second language research: Putting complexity theory into practice. The Modern Language Journal, 100(4): 741-756. DOI: https://doi.org/10.1111/modl.12347

Housen, A., Kuiken, F. and Vedder, A. 2012 Complexity, accuracy and fluency: Definitions, measurement and research. In Housen, A., Kuiken, F. and Vedder, A. Dimensions of L2 performance and proficiency: Complexity, accuracy and fluency in SLA. Amsterdam/Philadelphia, PA: John Benjamins. pp. $1-20$.

Ingvarsdóttir, H. and Arnbjörnsdóttir, B. 2013 ELF and academic writing: A perspective from the Expanding Circle. Journal of English as a Lingua Franca, 2(1): 123-145. DOI: https://doi.org/10.1515/jelf-2013-0006

Kyle, K. and Crossley, S. 2018 Measuring syntactic complexity in L2 writing using fine-grained clausal and phrasal indices. The Modern Language Journal, 102(2): 333-349. DOI: https://doi.org/10.1111/modl.12468

Larsen-Freeman, D. 1997 Chaos/complexity science and second language acquisition. Applied Linguistics, 18(2): 141-165. DOI: https://doi.org/10.1093/ applin/18.2.141

Larsen-Freeman, D. 2007 On the complementarity of chaos/complexity theory and dynamic systems theory in understanding the second language acquisition process. Bilingualism: Language and Cognition, 10(1): 35-37. DOI: https://doi.org/10.1017/S136672890600277X

Lowie, W. 2017 Lost in state space? Methodological considerations in Complex Dynamic Theory approaches to second language development research. In Ortega, L. and Han, Z. Complexity theory and language development: In celebration of Diane Larsen-Freeman. Amsterdam/Philadelphia, PA: John Benjamins. pp. 123-141.

Lu, X. 2011 A corpus-based evaluation of syntactic complexity measures as indices of college-level ESL writers' language development. TESOL Quarterly, 45(1): 36-62. DOI: https://doi.org/10.5054/tq.2011.240859

Manchón, R. 2015 The linguistic component of L2 written literacy in academic settings: Advancing research agendas on the interaction between writing and language. The 2015 Symposium on Second Language Writing, Auckland, New Zealand, 20 November 2015. 
Manchón, R. (ed.) 2012 L2 writing development: Multiple perspectives. Boston, MA/Berlin: de Gruyter Mouton.

Norris, J. 2015 Statistical significance testing in second language research: Basic problems and suggestions for reform. Language Learning, 65(S1): 97-126. DOI: https://doi.org/10.1111/lang.12114

Norris, J. and Ortega, L. 2009 Towards an organic approach to investigating CAF in instructed SLA: The case of complexity. Applied Linguistics, 30(4): 555-578. DOI: https://doi.org/10.1093/applin/amp044

Ortega, L. 2003 Syntactic complexity measures and their relationship to L2 proficiency: A research synthesis of college-level L2 writing. Applied Linguistics, 24(4): 492-518. DOI: https://doi.org/10.1093/applin/24.4.492

Ortega, L. 2015 Syntactic complexity in L2 writing: Progress and expansion. Journal of Second Language Writing, 29(1): 82-94. DOI: https://doi. org/10.1016/j.jslw.2015.06.008

Polat, B. and Kim, Y. 2014 Dynamics of complexity and accuracy: A longitudinal case study of advanced untutored development. Applied Linguistics, 35(2): 184-207. DOI: https://doi.org/10.1093/applin/amt013

Polio, C. and Park, J. 2016 Language development in second language writing. In Manchón, R. and Matsuda, P. Handbook of second and foreign language writing. Berlin: DeGruyter. pp. 287-306.

Spoelman, M. and Verspoor, M. 2010 Dynamic patterns in development of accuracy and complexity: A longitudinal case study in the acquisition of Finnish. Applied Linguistics, 31(1): 532-553. DOI: https://doi.org/10.1093/ applin/amq001

van Dijk, M. and van Geert, P. 2007 Wobbles, humps and sudden jumps: A case study of continuity, discontinuity and variability in early language development. Infant and Child Development, 16(1): 7-33. DOI: https://doi. org/10.1002/icd.506

van Dijk, M., Verspoor, M. and Lowie, W. 2011 Variability and DST. In Verspoor, M., de Bot, K. and Lowie, W. A dynamic approach to second language development: Methods and techniques. Amsterdam/Philadelphia, PA: John Benjamins. pp. 55-84.

van Geert, P. 2009 A comprehensive dynamic systems theory of language development. In de Bot, K. and Schrauf, R. Language development over the lifespan. New York: Routledge. pp. 60-104.

van Geert, P. 2011 The contribution of complex dynamic systems to development. Child Development Perspectives, 5(4): 273-278. DOI: https://doi.org/10.1111/ j.1750-8606.2011.00197.x

van Geert, P., Steenbeek, H. and Kunnen, S. 2012 Monte Carlo techniques: Statistical simulation for developemental data. In Kunnen, S. A dynamic systems approach to adolescent development. London/New York: Psychology Press. pp. 43-51.

Verspoor, M. 2017 Complex dynamic systems theory and L2 pedagogy. In Ortega, L. and Han, Z. Complexity Theory and language development: In 
celebration of Diane Larsen-Freeman. Amsterdam/Philadelphia, PA: John Benjamins. pp. 143-162.

Verspoor, M., Lowie, W., Chan, H. and Vahtrick, L. 2017 Linguistic complexity in second language development: Variability and variation at advanced stages. Recherches en didactique des langues et des cultures, 14, 1-27.

Verspoor, M., Lowie, W. and van Dijk, M. 2008 Variability in second language development from a dynamic systems perspective. The Modern Language Journal, 92(2): 214-231. DOI: https://doi.org/10.1111/j.15404781.2008.00715.x

Witherington, D. 2007 The dynamic systems approach as metatheory for developmental psychology. Human Development, 50: 127-153. DOI: https://doi.org/10.1159/000100943

Wolfe-Quintero, K., Inagaki, S. and Kim, H. 1998 Second language development in writing: Measures of fluency, accuracy, and complexity. Manoa: Second Language Teaching and Curriculum Center, University of Hawai'i.

Yang, W. and Sun, Y. 2015 Dynamic development of complexity, accuracy, and fluency in multilingual learners' L1, L2 and L3 writing. Theory and Practice in Language Studies, 5(2): 298-308. DOI: https://doi.org/10.17507/ tpls.0502.09

Yoon, H. 2017 Linguistic complexity in L2 writing revisited: Issues of topics, proficiency, and construct multidimensionality. System, 66: 130-141. DOI: https://doi.org/10.1016/j.system.2017.03.007 